Kalamatika: Jurnal Pendidikan Matematika

Volume 6, No. 2, April 2021, pages 1- 14

\title{
MATHEMATICS TEACHERS' RESPONSE TO ONLINE LEARNING DURING THE COVID-19 PANDEMIC: CHALLENGES AND OPPORTUNITIES
}

\author{
Yovika Sukma ${ }^{1}$, Nanang Priatna ${ }^{2}$ \\ ${ }^{1}$ Universitas Pendidikan Indonesia, Jl. Dr. Setiabudi No. 229, Bandung, Indonesia. \\ yovikasukma@upi.edu \\ ${ }^{2}$ Universitas Pendidikan Indonesia, Jl. Dr. Setiabudi No. 229, Bandung, Indonesia. \\ nanang_priatna@upi.edu
}

\section{ABSTRACT}

The Indonesian government made several policies to reduce the coronavirus spread, including in the education sector, by implementing online learning from home. This study aims to determine the mathematics teachers' perception of online learning implementation during COVID-19 related to its challenges and opportunities. The method used in this study was an exploratory method in which the researchers use d the questionnaire to gather the information. A total of 65 mathematics teachers from various education levels around South Sumatra, Indonesia, beca me the respondents. Based on the analysis of 65 mathematics teachers' responses, more than half of the respondents used the WhatsApp platform to carry out online learning activities. In implementing online learning, there were some challenges faced by mathematics teachers, such as students who did not have the facilities required for online learning. Although teachers still faced challenges, the teacher stated that online learning provided opportunities for teachers to upgrade themselves and learn more about educational technology. Moreover, online learning provided opportunities for students to communicate with other students and teachers alike unlimited by time. This study could provide an overview and information related to challenges and opportunities in implementing online learning for mathematics, which can be used in online learning activities during the COVID-19 pandemic.

\section{ARTICLE INFORMATION}

\begin{tabular}{lll}
\hline Keywords & & Article History \\
\hline COVID-19 & & Submitted Jul 23, 2020 \\
Pandemic & & Revised Mar 17, 2021 \\
Online learning & & Accepted Mar 22, 2021 \\
Mathematics teacher & & \\
\cline { 1 - 1 } Corresponding Author & \\
\hline
\end{tabular}

Yovika Sukma

Universitas Pendidikan Indonesia

Jl. Dr. Setiabudi No. 229, Bandung, Indonesia.

Email: yovikasukma@upi.edu

\section{How to Cite}

Sukma, Y. \& Priatna, N. (2021). Mathematics Teachers' Response to Online Learning during the COVID-19

Pandemic: Challenges and Opportunities. Kalamatika: Jurnal Pendidikan Matematika, 6(1), 1-14.

https://doi.org/10.22236/KALAMATIKA.vol6no1.2021pp1-14 


\section{INTRODUCTION}

Coronavirus disease (COVID-19) pandemic is an ongoing global problem hitting more than 200 countries in the world (Setiati \& Azwar, 2020). The first cases of COVID-19 in Indonesia were identified on March 2, 2020. Since the end of August 2020, the number of new positively tested cases in Indonesia has reached more than two thousand per day (Nugraha et al., 2020). To curb the coronavirus spread, the Indonesian government has made several policies, including policies in the education sector. One of the policies in the field of education is implementing online learning activities based on the Circular Letter by the Minister of Education and Culture of the Republic of Indonesia Number 36962 / MPK.A / HK / 2020 dated March 17, 2020. The online learning policies from home apply to all levels of education. Besides minimizing the coronavirus's spread, online learning policies also reduce coronavirus infection potential. Based on evidence and assumptions from influenza outbreaks, the application of online learning from home can reduce social contact among students so it can cut off the transmission of the virus (Jackson et al., 2016).

Online learning is not a new thing in f education. It is a learning activity using the internet to access learning materials, interact with teachers and other students, and gain knowledge (Moore et al., 2011). The characteristic of online learning is that learning activities can be done flexibly and do not prioritize location (Bower et al., 2015). Online learning can be carried out by utilizing various platforms such as social networking, learning management systems (LMS) such as Edmodo, Google Classroom, Moodle, and others. Learning materials, learning videos, and other information related to learning can be shared by teachers using Google Classroom, Moodle, and others (Varalakshmi \& Arunachalam, 2020).

Some studies related to online learning have been conducted previously. Some studies about online learning were related to online learning effects compared to face-to-face learning (Chu et al., 2017; Lo \& Hew, 2020). Previous research results showed that students who learn in online mode have higher achievement than those who learn face-to-face (Chu et al., 2017; Lo $\&$ Hew, 2020). Besides, online learning also has drawbacks. Among them is the lower quality of interactions (Dumford \& Miller, 2018). However, limited research paid attention to the teacher's response to online learning related to its challenges and opportunities.

Therefore, this study aims to determine the mathematics teachers' perception of online learning during COVID-19. The term perception in this study is defined as a tendency to respond 
to online learning, challenges faced in implementing online learning, and the opportunities to implement online learning. This study could provide an overview and information related to challenges and opportunities in implementing online learning for mathematics during the COVID-19 pandemic.

\section{METHOD}

The method used in this study was an exploratory method in which the researchers used questionnaires to gather information. The questionnaire was used to determine the mathematics teachers' perception of online learning implementation. The expression perception in this study was represented as a tendency to respond to online learning, challenges faced in implementing online learning, and the opportunities to implement online learning. There are seventeen questions related to the implementation of online learning. The sample of question items in the questionnaire is shown in Figure 1. The phone call interviews were then conducted to get the confirmation and detailed information on the respondents' responses in the questionnaire. As a guide to this study, three research questions were used to develop the questionnaire and analyze the data. The research questions are (1) how do mathematics teachers implement online learning?; (2) what challenges are faced ?; and (3) what opportunities do mathematics teachers have to improve the quality of learning?. The rubric for the questionnaire development is presented in Table 1.

Table 1. Questionnaire Rubric

\begin{tabular}{lrr}
\hline Indicator & Question Number & Number of Questions \\
\hline The implementation of online learning & $1,2,3,4,5,9,10$ & 7 \\
The challenges faced by mathematics teachers & $6,7,8,11,12$ & 5 \\
The opportunities to improve thequality of learning & $13,14,15,16,17$ & 5 \\
\hline
\end{tabular}

The subjects of this study were mathematics teachers in South Sumatera, Indonesia. A total of 65 mathematics teachers from various education levels around South Sumatera, Indonesia, were involved as the research respondents. The sampling technique used was the convenience sampling method based on respondents' availability to fill out the questionnaire. Respondents' data in this study are presented in Table 2.

Table 2. Respondent Data

\begin{tabular}{lcr}
\hline & Respondents & \multicolumn{1}{c}{ Percenta ge } \\
\hline School-level teaching & Elementary school & $44,6 \%$ \\
& Secondary school & $55,4 \%$ \\
Teaching experience & < 3 Years & $13,8 \%$ \\
& 3 - 6 Years & $49,2 \%$ \\
& > 6 Years & $36,9 \%$ \\
\hline
\end{tabular}




\section{Persepsi Guru Tentang Online Learning Selama} Pandemi Covid-19

Penelitian ini dilakukan untuk mengetahui persepsi guru tentang penerapan kegiatan pembelajaran secara online selama masa pandemi covid-19 ini. Data yang terkumpul bersifat rahasia dan hanya digunakan untuk

kepentingan penelitian semata tanpa dipublikasikan ke pihak yang tidak bertanggung jawab. Identitas diri Bapak/lbu juga bersifat pribadi, hanya diketahui oleh Penulis saja.

Alamat email *

Alamat email yang valid

Formulir ini mengumpulkan alamat email. Ubah setelan

Apakah sekolah Bapak/lbu baru menerapkan pembelajaran online semenjak pandemi covid-19? *

ıуа

Tidak
Translation:

Teachers' Perceptions of Online Learning during the COVID-19 Pandemic

This study is conducted to determine teachers' perceptions about the implementation of online learning activities during the COVID-19 pandemic. The collected data is confidential and only used for research purposes without published to the other parties. Your identity, known to the author only.

First Question:

Does your school implement online learning only since the COVID-19 pandemic?

○ Yes

○ No.

Figure 1. The Sample of Question Item in The Questionnaire

\section{RESULT AND DISCUSSION}

During the COVID-19 pandemic, Indonesia's school learning activities are implemented online, including in South Sumatra. This study aims to determine the mathematics teachers' perception of online learning implementation, challenges faced in implementing online learning, and the opportunities in implementing online learning during COVID-19. Online learning is not new in the field of education. However, respondents' answers (Figure 2) show that $95 \%$ of the total respondents have just implemented online learning.

The online questionnaire results show that teachers implement online learning activities by using online learning platforms. In the online questionnaire, teachers were asked to choose the type of platform used for online learning. In the questionnaire, teachers can choose more than one type of platform. The answers (Figure 3) show that $89.23 \%$ of the respondents used WhatsApp for online learning. 


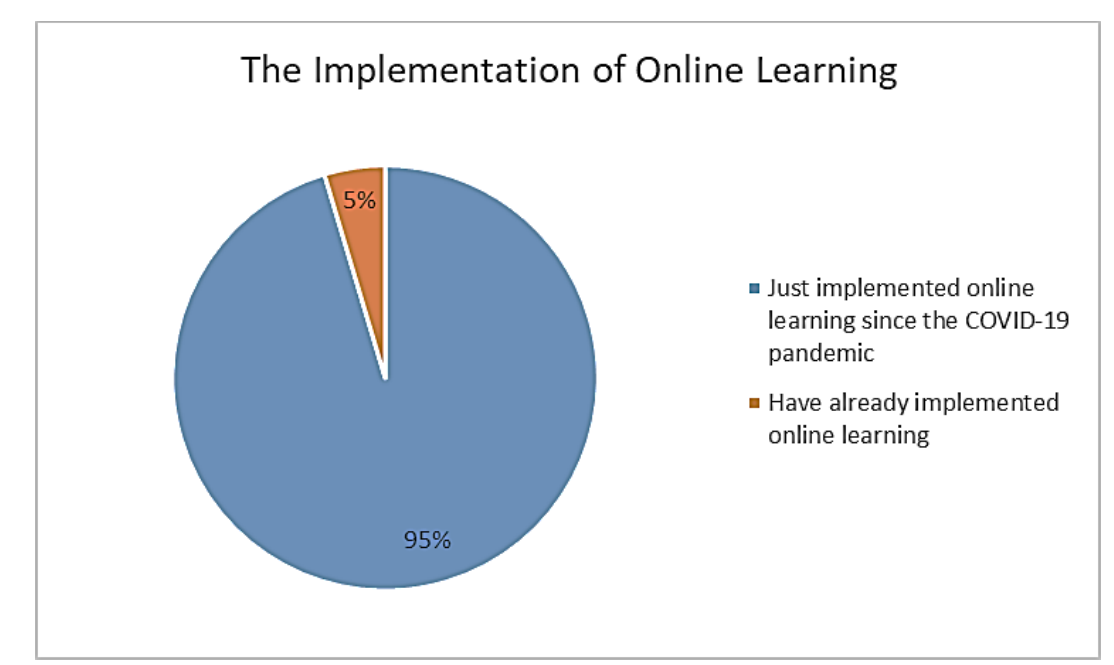

Figure 2. The Online Learning Implementation Diagram

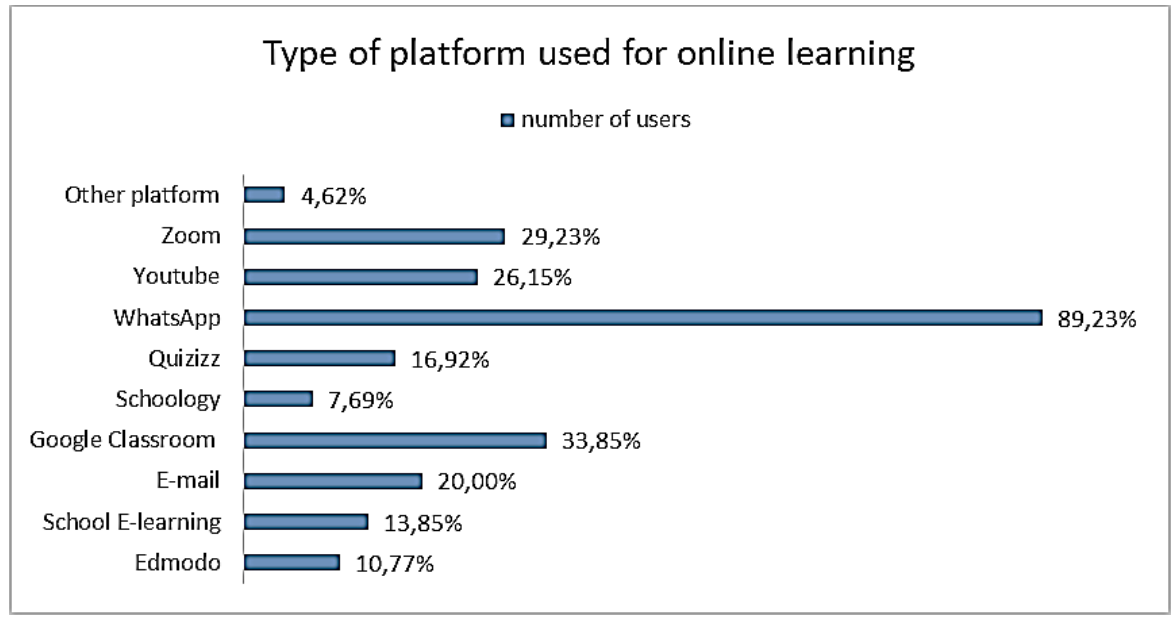

Figure 3. Types of Platform used by Teachers for Online Learning

Besides choosing the type of platform, teachers were also asked to choose the online learning activities. Based on the results (Figure 4), $75.38 \%$ of respondents carried out learning activities by asking students to read the learning materials first and then assigning exercises to them.

Although learning is conducted online, the teacher still prepared learning materials before starting teaching and provided feedback to students during the learning process. That could be seen from the online questionnaire results (Figure 5), where $91 \%$ of respondents stated that they prepared learning materials before teaching (Figure 5a), and 80\% of respondents said that feedbacks were provided to students during online learning (Figure 5b). 


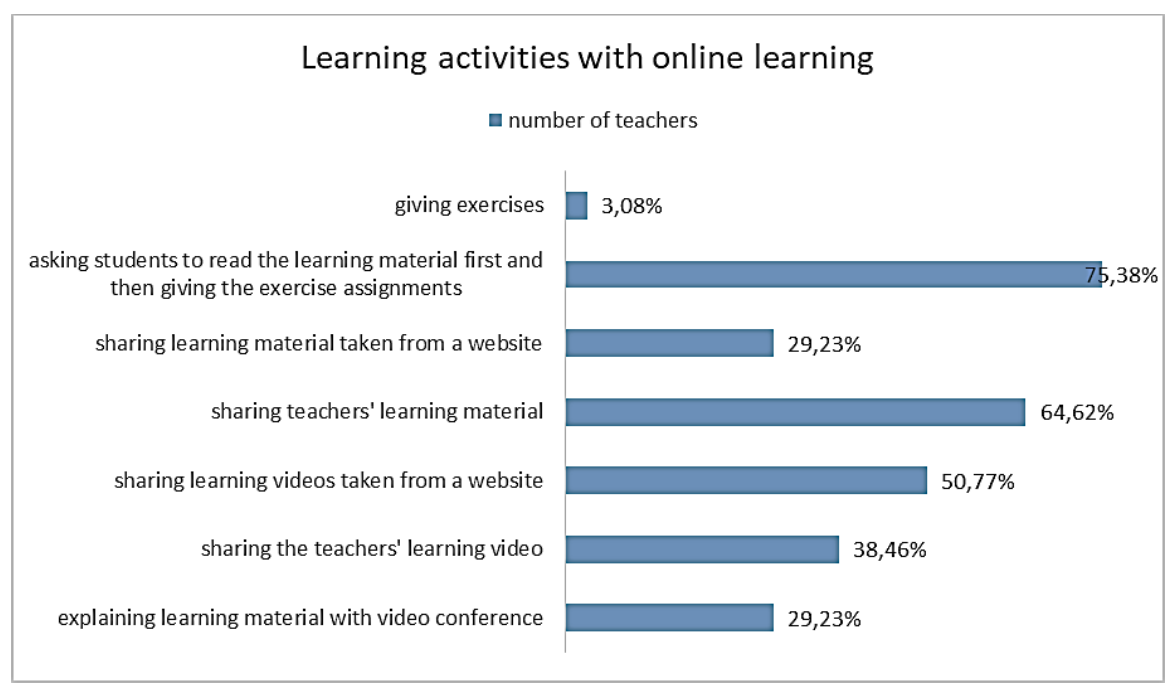

Figure 4. Learning Activities with Online Learning

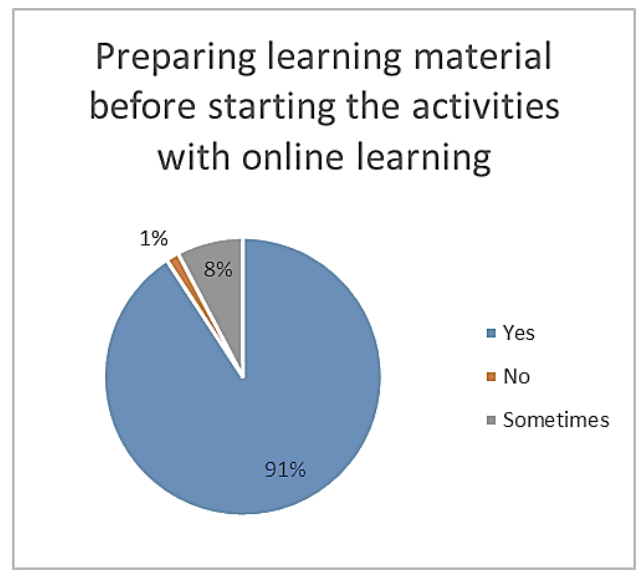

(a)

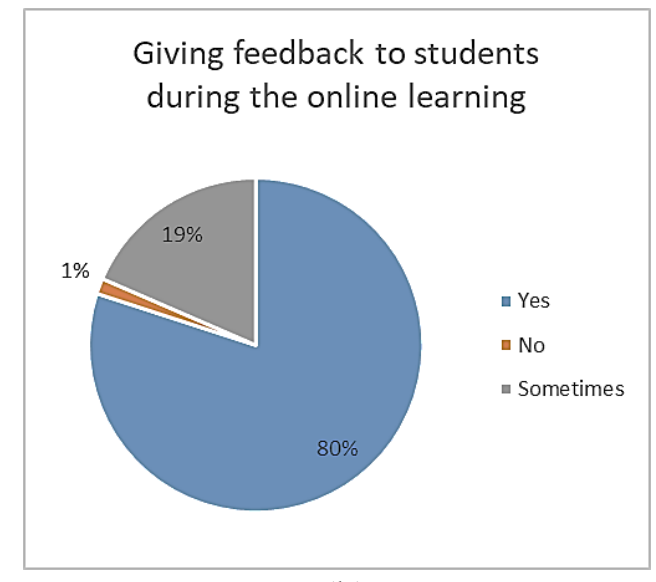

(b)

Figure 5. Questionnaire responses

Moreover, during the implementation of online learning, 96.9\% of respondents experienced some significant obstacles. Furthermore, $67.69 \%$ of respondents stated that the constraints were due to students who did not have the facilities to learn online (Figure 6). Despite the challenges for online teaching, $69.2 \%$ of respondents considered that they were getting used to online learning. Moreover, $70.8 \%$ of respondents chose Zoom as an effective platform for online learning and for achieving the learning objectives. 


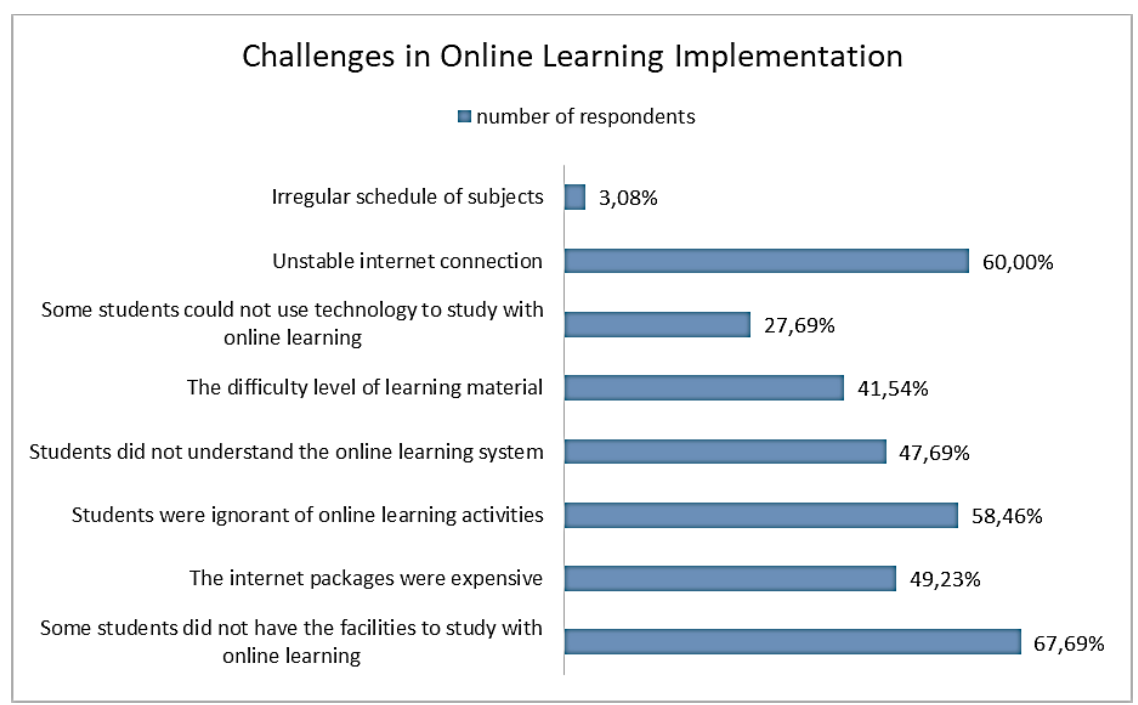

Figure 6. Challenges Faced by Teachers during Online Learning

\section{The Implementation of Online Learning by Mathematics Teachers}

One of the characteristics of online learning is implementing learning activities could be done flexibly or without being limited by place and time (Bower et al., 2015). During the COVID-19 pandemic, learning activities continued to be carried out online from home. When this study was conducted, all schools in Indonesia were still implementing online learning, including in South Sumatra. Even online learning is not a new thing in education; 95\% of respondents responded that they had just implemented online learning because they had to carry out online learning during the COVID-19 pandemic. Based on the interviews, some respondents stated that they were familiar with face-to-face learning only. Therefore, they find it a little tricky and confused when implementing online learning. Some respondents stated that they knew how to implement online learning by following school instructions and directions.

Based on the respondents' answers, all of the respondents stated that schools were advised to use the online learning platform for conducting online learning. Some teachers stated that the choice of platform was based on ease of access by students. Moreover, Figure 3 shows that most mathematics teachers used WhatsApp for learning. The WhatsApp platform was chosen because it was more accessible for students as they can access it via their smartphones. After all, almost all students have a mobile phone and WhatsApp account. The mobile phone is the most popular technology nowadays, including among students (Ismail et al., 2018). Students preferred to study using their mobile phones rather than laptops (Hew \& Lo, 2020).

Besides choosing the type of platform, teachers stated that learning activities with online 
learning were also chosen by considering easy access. Figure 4 shows that most of the respondents carried out learning activities by asking students to read the learning material first and then asked them to do exercises. Furthermore, in online learning, the teacher is still prepared to learn the material before teaching provided feedback to students during the learning process. That could be seen from Figure 3 that $91 \%$ of respondents prepared to learn the material before teaching, and $80 \%$ of respondents gave feedback to students during online learning. The teacher gave feedback on the exercises doneby students. The questionnaire results reveal that they gave feedback to students so that they can understand better the topic being studied and motivate them to continue their enthusiasm for learning online.

Based on the questionnaire and interview results, most teachers were new to online learning. Almost all the teachers responded using WhatsApp as a learning platform for online learning because WhatsApp is considered a platform that most students use, and most students are familiar with the application. Using WhatsApp, teachers asked students to read the learning material and assigned exercises. However, teachers still prepared the teaching materials before teaching and continued to provide feedback to students.

\section{The Challenges Faced by Mathematics Teachers}

During the implementation of online learning, most of the respondents faced significant obstacles. Figure 4 shows that $67.69 \%$ of respondents stated that the constraints were due to students who did not have the facilities to learn online. Furthermore, the teacher stated that by online learning, learning objectives could not be achieved. $64.6 \%$ of respondents confirmed that learning online did not achieve the learning objectives. Besides, based on teachers' experience while implementing online learning, learning activities with online learning were not improving student learning outcomes. The online questionnaire results; $63.1 \%$ of respondents stated that online learning did not improve students' learning outcomes. Moreover, according to some of the teachers' answers on the interview, online learning did not support the improvement of students' learning outcomes.

According to $70.7 \%$ of respondents, the platform that could improve student learning outcomes was Zoom. Because by using the Zoom platform, the teachers could directly explain the learning material through video conferencing. Video explanation with zoom is considered similar to explaining the material directly in the face-to-face classroom (Hew \& Lo, 2020). Furthermore, online tutoring allows students to master the concepts, and their mathematics 
ability improves (Clark et al., 2014). However, according to some teachers, the Zoom platform could not be used for every meeting because it requires internet lot of internet data pa a stable signal. Thus, for teachers who teach outside urban areas, the Zoom's use was hard to implement due to unstable internet access and the high price of internet packages.

The teachers also said that another challenge in using the Zoom platform was to explain sub-subjects that need explanation by way of writing. It became a challenge because there is no feature for mathematical typing on the Zoom platform. Explaining the topic that required mathematical typing could have been done by sharing the screen on the Zoom platform and then using MSWord to write the mathematical symbols, but this technique was not so effective. In turn, for mathematical typing symbols, teachers could use LaTeX as a stand ard for the quality of mathematical typesetting (Sangwin, 2015). However, only a few teachers know LaTeX. They only knew the mathematical typing features in MSWord, which had inferior support for mathematics (Sangwin, 2015). Therefore, for an explanation that requires showing the steps in solving a problem, the teachers preferred to record their explanatory videos and share the video link to students through the WhatsApp group.

Another challenge was that students were ignorant of assignments during online learning and did not always submit the assignments given by the teacher. From interviews with teachers, this due to students' inability to manage time. Some teachers said that their students often said they did not have time to make the assignments because they had to do other subjects' assignments. The results of previous studies stated that students' ability to adjust learning schedules was one of the self-regulation abilities (Rahmawati et al., 2015). Students' selfregulation is needed for success in learning (McDonald, 2014), including online. In turn, teachers have to foster students' self-regulation so that learning activities could take place well and the learning objectives can be achieved.

\section{The Opportunities Mathematics Teachers have to Improve the Quality of Learning.}

Online learning during the COVID-19 pandemic requires teachers to use technology to learn and achieve learning objectives. The use of technology in learning activities is common in most educational institutions (Moradimokhles \& Hwang, 2020). The respondents said that they had become accustomed to online learning and the use of technology. The policy to do online learning has allowed teachers to upgrade themselves and learn educational technology and online learning platforms. Besides, implementing online learning has allowed teachers to 
develop their creativity to make fun of learning activities and make them easily accessible to students. Online learning also allows students to communicate with other students and teachers without being limited by time (Dumford \& Miller, 2018).

Moreover, discussion with the online learning platform allows students to reflect on themselves and collaborate with other students to broaden their understanding of learning material (Alexander et al., 2019). Students could accept the diversity of views of a material topic through discussions using online learning platforms because students accept explanatory arguments from the teachers and other students (Kashefi et al., 2012; Naidoo et al., 2016). Furthermore, when students struggle with problems, they have additional opportunities to discuss with other students (Roschelle et al., 2016) or asking for help from their teachers directly without the need to feel ashamed of other students' judgment (Sum \& Kwon, 2020). Besides, discussions using the online platform encourage students to participate in discussions actively (Naidoo et al., 2016).

Moreover, the teachers stated that online learning allows teachers to provide personalized feedback and immed iately hints to each student to know what they have done right or wrong (Roschelle et al., 2016). With the use of technology in online learning, teachers become more sophisticated in delivering assessments and analyzing student performance (Hoogland \& Tout, 2018).

\section{CONCLUSION}

Based on the analysis of 65 mathematics teachers' responses, more than half of the respondents used the WhatsApp platform to carry out learning activities during online learning. The WhatsApp platform was chosen because it was more accessible for students to access via mobile phones. Also, almost all of the students have mobile phones and WhatsApp accounts. During the learning activities with WhatsApp, the teacher asked students to read the learning material first and then assigned exercises to them. However, teachers still did preparation for the teaching before and continued to provide feedback to students about the results of students' exercises to make students more understand the material being studied.

While carrying out online learning activities, there were several challenges faced by mathematics teachers; (1) some students did not have the facilities to learn with online learning, (2) the use of learning platforms that did not improve student learning outcomes, (3) signal instability and the high cost of internet data (4) the difficulty of explaining topics that required 
teachers to explain the completion steps by writing mathematical symbols, and (5) the presence of students who were ignorant of the teacher's assignments on online learning.

Although teachers still faced many challenges, the teachers stated that online learning allowed teachers to upgrade themselves and learn more about educational technology. Besides, online learning also allowed students to communicate with other students and teachers unlimited by time. This study was limited by analysis of the responses of teachers who became respondents. Further researchers are suggested to study online learning applications in mathematics and their effects on student learning outcomes during the COVID-19 pandemic.

\section{REFERENCES}

Alexander, N. N., Teymuroglu, Z., \& Yerger, C. R. (2019). Critical Conversations on Social Justice in Undergraduate Mathematics. Primus, 29(3-4), 396-419. https://doi.org/10.1080/10511970.2018.1530704

Bower, M., Dalgarno, B., Kennedy, G. E., Lee, M. J. W., \& Kenney, J. (2015). Design and implementation factors in blended synchronous learning environments: Outcomes from a cross-case analysis. Computers and Education, 86, 1-17. https://doi.org/10.1016/j.compedu.2015.03.006

Chu, H., Chen, J., \& Tsai, C. (2017). Effects of an online formative peer-tutoring approach on students ' learning behaviors, performance, and cognitive load in mathematics. Interactive Learning Environments, 203-219. https://d oi.org/10.1080/10494820.2016.1276085

Clark, A. K., Whetstone, P., Clark, A. M. Y. K., \& Mcgraw-hill, C. T. B. (2014). The Impact of an Online Tutoring Program on Mathematics Achievement. The Journal of Education Research, 107(6), 462-466. https://doi.org/10.1080/00220671.2013.833075

Dumford, A. D., \& Miller, A. L. (2018). Online learning in higher education: Exploring advantages and disadvantages for engagement. Journal of Computing in Higher Education, 30(3), 452-465.

Hew, K. F., \& Lo, C. K. (2020). Comparing video styles and study strategies during videorecorded lectures: Effects on secondary school mathematics students' preference and 
learning. Interactive Learning Environments, 28(7), 847-864. https://doi.org/10.1080/10494820.2018.1545671

Hoogland, K., \& Tout, D. (2018). Computer-based assessment of mathematics into the twentyfirst century: pressures and tensions. ZDM, 50(4), 675-686. https://d oi.org/10.1007/s11858-018-0944-2

Ismail, N. S., Harun, J., Zakaria, M. A. Z. M., \& Salleh, S. M. (2018). The effect of Mobile problem-based learning application DicScience PBL on students' critical thinking. Thinking Skills and Creativity, 28, 177-195. https://doi.org/10.1016/j.tsc.2018.04.002

Jackson, C., Vynnycky, E., \& Mangtani, P. (2016). The Relationship between School Holidays and Transmission of Influenza in England and Wales. American Journal of Epidemiology, 184(9), 644-651. https://doi.org/10.1093/aje/kww083

Kashefi, H., Ismail, Z., Yusof, Y. M., \& Rahman, R. A. (2012). Supporting Students Mathematical Thinking in the Learning of Two-Variable Functions Through Blended Learning. Procedia - Social and Behavioral Sciences, 46, 3689-3695. https://d oi.org/10.1016/j.sbspro.2012.06.128

Lo, C. K., \& Hew, K. F. (2020). A comparison of flipped learning with gamification, traditional learning, and online independent study: the effects on students' mathematics achievement and cognitive engagement. Interactive Learning Environments, 28(4), 464481. https://doi.org/10.1080/10494820.2018.1541910

McDonald, P. L. (2014). Variation in Adult Learners' Experiences of Blended Learning in Higher Education. Blended Learning: Research Perspectives, 2, 215-234.

Moore, J. L., Dickson-Deane, C., \& Galyen, K. (2011). E-Learning, online learning, and distance learning environments: Are they the same? Internet and Higher Education, 14(2), 129-135. https://doi.org/10.1016/j.iheduc.2010.10.001

Moradimokhles, H., \& Hwang, G. J. (2020). The effect of online vs. blended learning in developing English language skills by nursing students: an experimental study. Interactive 
https://doi.org/10.1080/10494820.2020.1739079

Naidoo, K., Naidoo, R., \& Ramdass, K. (2016). Comparing a Hybrid Mathematics Course with a Conventional Mathematics Course: A Case Study at a University of Technology. International Journal of Educational Sciences, 15(3), 392-398. https://doi.org/10.1080/09751122.2016.11890549

Nugraha, B., Wahyuni, L. K., Laswati, H., Kusumastuti, P., Tulaar, A. B. M., \& Gutenbrunner, C. (2020). COVID-19 Pandemic in Indonesia: Situation and Challenges of Rehabilitation Medicine in Indonesia. Acta Medica Indonesiana, 52(3), 299-305.

Rahmawati, I. L., Hartono, H., \& Nugroho, S. E. (2015). Pengembangan Asesmen Formatif untuk Meningkatkan Kemampuan Self Regulation Siswa pada Tema Suhu dan Perubahannya. Unnes Science Education Journal, 4(2).

Roschelle, J., Murphy, R. F., \& Mason, C. A. (2016). Online Mathematics Homework Increases Student Achievement. 2(4). https://doi.org/10.1177/2332858416673968

Sangwin, C. (2015). Computer-Aided Assessment of Mathematics Using STACK. In Selected regular lectures from the 12th international congress on mathematical education (pp. 695-713). Springer, Cham. https://doi.org/10.1007/978-3-319-17187-6

Setiati, S., \& Azwar, M. K. (2020). COVID-19 and Indonesia. Acta Medica Indonesiana, 52(1), 84-89.

Sum, E. S. W., \& Kwon, O. N. (2020). Classroom talk and the legacy of Confucian culture in mathematics classroom. Teaching and Teacher Education, 88, 102964. https://doi.org/10.1016/j.tate.2019.102964

Varalakshmi, R., \& Arunachalam, K. (2020). COVID 2019 - Role of Faculty Members to Keep Mental Activeness of Students. 51, 102091. 
14 KALAMATIKA, Volume 6, No. 1, April 2021, pages 1-14 